\title{
RELATIONS BETWEEN THE NODAL EXTERNAL FORCES AND THE NODAL DISPLACEMENTS ON THE BOUNDARY FRAMES OF RECTANGULAR ELASTIC FRAMED SHEAR WALLS PART IV
}

\author{
Stiffness Matrices and Flexibility Matrices-
}

\author{
By MASAHIDE TOMII* and TETSUO YAMAKAWA** \\ Members of A.I.J.
}

\begin{abstract}
PREFACE
As the pages are limited, the paper of this main title is separated into 5 Parts. The following Parts :

Part I Relations between the Nodal External Forces and the Representative Components of Their Fundamental Components $(\$ 1, \S 2)$

Part II Relations between the Nodal Displacements and the Representative Components of Their Fundamental Components $(\$ 3, \S 4)$

Part III General Relations between the Nodal External Forces and the Nodal Displacements $(\$ 5, \S 6)$
\end{abstract}

were reported in the previous Transactions No. 237, 238 and 239 published in Nov., Dec. 1975 and Jan. 1976, and the following Part:

Part V A Numerical Example (\$10), Conclusions, Notation and References will be published in the following Transactions.

The aim of this paper was described in $\$ 1$ Introduction in Part $I$.

\section{$\$ 7$ Properties of the General Stiffness Matrix for the Nodes of the Boundary Frame of Framed Shear Walls}

As discussed in $\S 6$, the general stiffness matrix $\overline{\boldsymbol{K}}$ can be expressed in terms of the inverse matrix of the fundamental flexibility matrix $\boldsymbol{F}^{*}$ whose elements can be given analytically ${ }^{1 \sim 5}$ or must be given experimentally (see Eq. 6.7).

The symbols $k_{m . n}$ of the elements of the general stiffness matrix $\overline{\boldsymbol{K}}$ are defined as shown in Eq. 7.1 indicating $\overline{\boldsymbol{P}}_{\delta}{ }^{*}=\overline{\boldsymbol{K}} \overline{\boldsymbol{\partial}}$ (see Eq. 6.9) in detail. When the shape of the shear wall is symmetric with regard to its longitudinal and transversal center lines and the shear wall is an isotropic elastic body, these elements $k_{m . n}$ expressed in terms of the elements of the fundamental stiffness matrix $K^{*}$ (see Eq. 5.5) are shown in Table 7.1, where the elements of $\boldsymbol{K} *$ can be expressed in terms of the elements of $\boldsymbol{F}^{*}$ (see Eqs. 5.2, 5.5 and 5.6) whose elements can be given analytically ${ }^{1 \sim 5}$ or also be given experimentally.

* Professor of Structural Engineering, Department of Architecture, Faculty of Engineering, Kyushu University, Dr. Eng.

** Research Engineer, Research Laboratory of Shimizu Construction Company Ltd., Ma. Eng. 


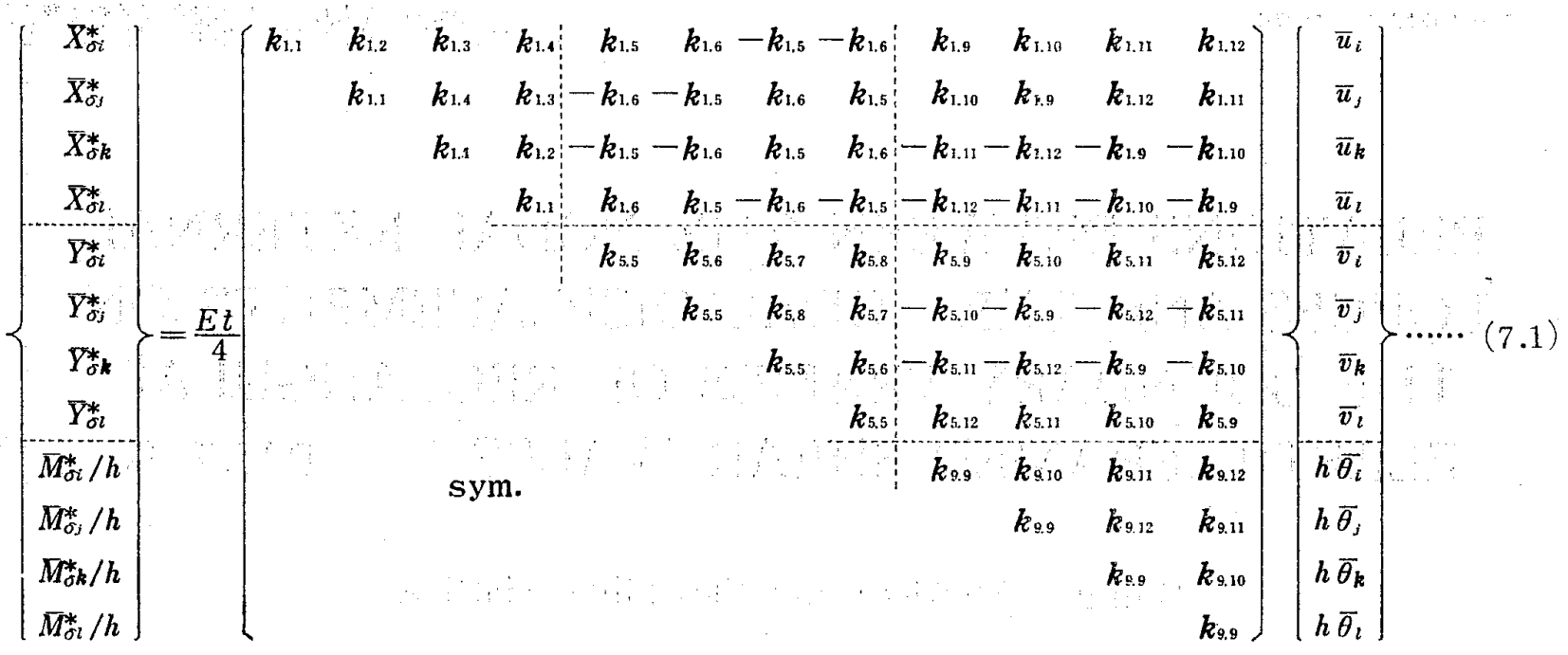

where

$k_{m . n}:$ The elements of the general stiffness matrix $\overline{\boldsymbol{K}}$ (for the four corner nodes of the boundary frame) of the shear wall (see Table 7.1)

Table 7.1 The elements $k_{m . n}$ of the general stiffness matrix $\bar{K}$ of symmetric shear walls, expressed in terms of the elements of the fundamental stiffness matrix $\boldsymbol{K}^{*}$ (see Eq. 5.5).

\begin{tabular}{|c|c|c|c|c|c|c|c|}
\hline$k_{1.1}$ & $\frac{a_{2.2}}{D_{I}}+\left(\frac{B_{1,1}}{D_{l l}}+\frac{d_{2.2}}{D_{N}}\right)$ & $k_{1.2}$ & $\frac{a_{2.2}}{D_{l}}-\left(\frac{B_{1.1}}{D_{l l}}+\frac{d_{2.2}}{D_{v}}\right)$ & $k_{1,3}$ & $-\frac{a_{2.2}}{D_{i}}-\left(\frac{B_{1.1}}{D_{l l}}-\frac{d_{2.2}}{D_{N}}\right)$ & $k_{1.4}$ & $-\frac{a_{2.2}}{D_{t}}+\left(\frac{B_{1.1}}{D_{t l}}-\frac{d_{2.2}}{D_{v}}\right)$ \\
\hline$k, 5$ & $-\frac{a_{1.2}}{D_{l}}+\frac{B_{1.2}}{D_{l l}}$ & $k_{1.6}$ & $\frac{a_{1.2}}{D_{l}}+\frac{B_{1.2}}{D_{l l}}$ & & & & \\
\hline$k_{1.9}$ & $\begin{array}{r}-\frac{1}{2 D_{l}}\left(a_{2.2}+\lambda a_{1.2}\right) \\
+\left(\frac{B_{1.3}}{D_{l l}}-\frac{d_{1.2}}{D_{l v}}\right)\end{array}$ & $k_{1,10}$ & $\begin{array}{r}-\frac{1}{2 D_{l}}\left(a_{2,2}+\lambda a_{1,2}\right) \\
-\left(\frac{B_{1.3}}{D_{l l}}-\frac{d_{1,2}}{D_{N V}}\right)\end{array}$ & $k_{1,11}$ & $\begin{array}{r}-\frac{1}{2 D_{l}}\left(a_{2.2}+\lambda a_{1.2}\right) \\
\quad+\left(\frac{B_{1.2}}{D_{l l}}+\frac{d_{1.2}}{D_{N V}}\right)\end{array}$ & $k_{1,12}$ & $\begin{array}{r}-\frac{1}{2 D_{l}}\left(a_{2,2}+\lambda a_{1.2}\right) \\
-\left(\frac{B_{1.3}}{D_{l t}}+\frac{d_{1.2}}{D_{k}}\right)\end{array}$ \\
\hline$k_{5.5}$ & $\frac{a_{1.1}}{D_{1}}+\left(\frac{B_{2.2}}{D_{l l}}+\frac{C_{2.2}}{D_{I I I}}\right)$ & $k_{5.6}$ & $-\frac{a_{1.1}}{D_{l}}+\left(\frac{B_{2.2}}{D_{I I}}-\frac{c_{2.2}}{D_{I I I}}\right)$ & $k_{5.7}$ & $-\frac{a_{1.1}}{D_{l}}-\left(\frac{B_{2.2}}{D_{i l}}-\frac{C_{2.2}}{D_{I I}}\right)$ & $k_{5.8}$ & $\frac{a_{1,1}}{D_{l}}-\left(\frac{B_{2,2}}{D_{l l}}+\frac{C_{2,2}}{D_{l l}}\right)$ \\
\hline 9 & $\begin{array}{l}\frac{1}{2 D_{I}}\left(a_{1,2}+\lambda a_{1,1}\right) \\
\quad+\left(\frac{B_{2.3}}{D_{I I}}-\frac{c_{1.2}}{D_{I I I}}\right)\end{array}$ & $k_{5,10}$ & $\begin{array}{r}\frac{1}{2 D_{l}}\left(a_{1,2}+\lambda a_{1,1}\right) \\
-\left(\frac{B_{2,3}}{D_{I I}}+\frac{c_{1,2}}{D_{I I}}\right)\end{array} \mid$ & $k_{5.11}$ & $\begin{array}{l}\frac{1}{2 D_{I}}\left(a_{1.2}+\lambda a_{1,1}\right) \\
+\left(\frac{B_{2.3}}{D_{l l}}+\frac{c_{1.2}}{D_{I I}}\right)\end{array}$ & $k_{5.12}$ & $\begin{aligned} \frac{1}{2 D_{t}}\left(a_{1,2}\right. & \left.+\lambda a_{t, 1}\right) \\
& -\left(\frac{B_{2,3}}{D_{l l}}-\frac{c_{1,2}}{D_{l l}}\right)\end{aligned}$ \\
\hline$k_{9.9}$ & $\left\{\begin{array}{l}\frac{1}{4 D_{l}}\left(a_{2,2}+\lambda a_{1.2}\right) \\
+\frac{\lambda}{4 D_{I}}\left(a_{i .2}+\lambda a_{1.1}\right) \\
+\frac{B_{3.3}}{D_{I I}}+\left(\frac{c_{1.1}}{D_{I J}}+\frac{d_{l, 1}}{D_{N}}\right)\end{array}\right.$ & $k_{9 . \mathrm{i} 0}$ & $\begin{array}{l}\frac{1}{4 D_{l}}\left(a_{2.2}+\lambda a_{1,2}\right) \\
+\frac{\lambda}{4 D_{l}}\left(a_{1.2}+\lambda a_{1.1}\right) \\
-\frac{B_{3.3}}{D_{l l}}+\left(\frac{c .1}{D_{I I}}-\frac{d_{1,1}}{D_{l v}}\right)\end{array}$ & $k_{9,11}$ & $\begin{array}{l}\frac{1}{4 D_{l}}\left(a_{2.2}+\lambda a_{1.2}\right) \\
+\frac{\lambda}{4 D_{l}}\left(a_{1.2}+\lambda a_{1,1}\right) \\
+\frac{B_{3.3}}{D_{u}}-\left(\frac{C_{1.1}}{D_{I I}}+\frac{d_{1.1}}{D_{N}}\right)\end{array}$ & $k_{9.12}$ & $\begin{array}{l}\frac{1}{4 D_{l}}\left(a_{2.2}+\lambda a_{1.2}\right) \\
+\frac{\lambda}{4 D_{1}}\left(a_{1.2}+\lambda a_{1.1}\right) \\
-\frac{B_{3.3}}{D_{l l}}-\left(\frac{c_{1.1}}{D_{t u}}-\frac{d_{1.1}}{D_{l v}}\right)\end{array}$ \\
\hline
\end{tabular}

The general stiffness matrix $\overline{\boldsymbol{K}}$ has the following properties (see the numerical example mentioned in Eq. 10.9).

1) Each sum of all elements corresponding to the nodal external balancing forces $\bar{X}_{\delta}^{*}$ or $\bar{Y}_{\delta^{*}}$ in any column of $\overline{\boldsymbol{K}}$ is zero, therefore the equilibrium for the forces in the $\bar{x}$ and $\bar{y}$-directions is identically satisfied. However, the sum of all elements corresponding to the nodal external moments $\bar{M}_{\delta} *$ in any column of $\bar{K}$ is not zero, because the equilibrium for moment cannot be satisfied unless $\bar{X}_{\delta}^{*}$ and $\bar{Y}_{i} *$ are taken into consideration. But here, the sum of the elements corresponding to all $\bar{M}_{\delta}^{*}$, the modified elements $k_{m \cdot n} / 2$ corresponding to $\bar{X}_{\delta i}{ }^{*}$ and $\bar{X}_{\dot{o} j}{ }^{*}$, the modified elements 
$-k_{m, n} / 2$ corresponding to $\bar{X}_{\delta k^{*}}$ and $\bar{X}_{\delta t^{*}}$, the modified elements $-\lambda k_{m . n} / 2$ corresponding to $\bar{Y}_{\delta i}{ }^{*}$ and $\bar{Y}_{\delta l^{*}}{ }$, and the modified elements $\lambda k_{m . n} / 2$ corresponding to $\bar{Y}_{i j}{ }^{*}$ and $\bar{Y}_{i k}{ }^{*}$, in any column of $\overline{\boldsymbol{K}}$, is zero. Therefore the equilibrium for moment of nodal external balancing forces $\bar{X}_{\delta}^{*}, \bar{Y}_{\delta}^{*}$, $\bar{M}_{i}^{*}$ is identically satisfied.

2) Each sum of all elements corresponding to the nodal displacements $u$ or $\bar{v}$ in any row of $\overline{\boldsymbol{K}}$ is zero, therefore the nodal external forces and moments $\bar{X}_{0}^{*}, \bar{Y}_{i}^{*}, \bar{M}_{\delta}{ }^{*}$ are not affected by the nodal displacements $\bar{u}$ which equal the linear rigid-hody motion $u^{\circ}$ of the shear wall, or the nodal displacements $\bar{v}$ which equal the linear rigid-body motion $v^{\circ}$ of the shear wall. However the sum of all the elements corresponding to the nodal rotational angles $\bar{\theta}$ in any row of $\overline{\boldsymbol{K}}$ is not zero, because the nodal displacements :

$$
u_{i}=\bar{u}_{j}=-\bar{u}_{k}=-\bar{u}_{l}=\frac{h}{2} \theta^{\circ}, \quad \bar{v}_{i}=-\bar{v}_{j}=-\bar{v}_{k}=\bar{v}_{l}=-\frac{l}{2} \theta^{\circ}
$$

together with the nodal rotational angles $\bar{\theta}$ which equal $\theta^{\circ}$ are caused by the small rotational rigid-body motion $\theta^{\circ}$ of the shear wall (see Fig. 3.2). But here, the sum of the elements corresponding to all $\bar{\theta}$, the modified elements $k_{m . n} / 2$ corresponding to $\bar{u}_{i}$ and $\bar{u}_{j}$, the modified elements $-k_{m . n} / 2$ corresponding to $\bar{u}_{k}$ and $\bar{u}_{l}$, the modified elements $-\lambda k_{m . n} / 2$ corresponding to $\bar{v}_{i}$ and $\bar{v}_{l}$, and the modified elements $\lambda k_{m . n} / 2$ corresponding to $\overline{\mathfrak{v}}_{j}$ and $\bar{v}_{k}$, in any row of $\overline{\boldsymbol{K}}$, is zero. Here, the rotational rigid-body motion $\theta^{\circ}$ must be small, because this analysis is based on a linear small displacement theory. Therefore $\bar{X}_{\hat{\delta}^{*}}, \bar{Y}_{\hat{o}^{*}}$ and $\bar{M}_{\hat{\theta}}^{*}$ are not affected by the small rotational rigid-body motion $\theta^{\circ}$. Hence, the following Eq. 7.2 is induced.

$$
\overline{\boldsymbol{K}} \overline{\boldsymbol{\partial}^{\circ}}=\mathbf{0}
$$

3) $\overline{\boldsymbol{K}}$ is a syrnmetric matrix, therefore the reciprocal theorem can be applied if the nodal boundary conditions which definitely decide the nodal displacements are given.

4) When the descriptions in 1),2) and 3) are taken into consideration, three rows (columns), each respectively corresponding to $\bar{X}_{\dot{0}}^{*}, \bar{Y}_{\dot{\delta}}^{*}$ and $\bar{M}_{\dot{\delta}}{ }^{*}(\bar{u}, \bar{v}$ and $\ddot{\theta})$ or one corresponding to $\bar{X}_{\dot{\delta}}{ }^{*}$ $(\bar{u})$ and two corresponding to $\bar{Y}_{\dot{0}} *(\bar{v})$ whose lines of action do not coincide or two corresponding to $\bar{X}_{\delta}^{* *}(\bar{u})$ whose lines of action do not coincide and one corresponding to ${\overline{Y_{\delta}}}_{\delta}^{*}(\bar{v})$, are dependent rows (columns). Consequently the determinant of the matrix $\overline{\boldsymbol{K}}$ is zero.

$$
|\bar{K}|=\mathbf{0}
$$

Hence, $\overline{\boldsymbol{K}}$ is singular, and the general flexibility matrix $\overline{\boldsymbol{F}}$ mentioned in $\$ 8$ cannot be derived by

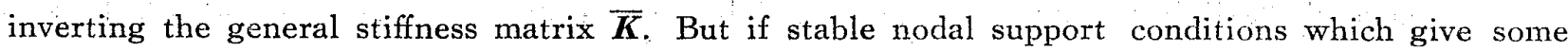
nodal displacements are imposed on the shear wall, the conditional flexibility matrix can be given by inverting the conditional stiffness matrix.

\section{$\$ 8$ Properties of the General Flexibility Matrix for the Nodes of the Boundary Frame of Framed Shear Walls}

As discussed in $\S 6$, the general flexibility matrix $\bar{F}$ can be expressed in terms of the fundamental flexibility matrix $F^{*}$ whose elements can be given analytically ${ }^{1 \sim 5}$ ) or must be given experimentally (see Eq. 6.20).

The symbols $f_{m . n}$ of the elements of the general flexibility matrix $\overline{\boldsymbol{F}}$ are defined as shown in Eq. 8.1 indicating $\overline{\boldsymbol{\partial}}_{P^{*}}=\overrightarrow{\boldsymbol{F}} \overline{\boldsymbol{P}}$ (see Eq. 6.21) in detail. When the shape of the shear wall is symmetric with regard to its longitudinal and transversal center lines and the shear wall is an isotropic elastic body, these elements $f_{m . n}$ expressed in terms of the fundamental flexibility matrix $\boldsymbol{F}^{*}$ (see Eq. 5.2) are shown in Table 8:1, where the elements of $\boldsymbol{F}^{*}$ can be given analytically ${ }^{1 \sim 5}$ ) or also be given experimentally. 


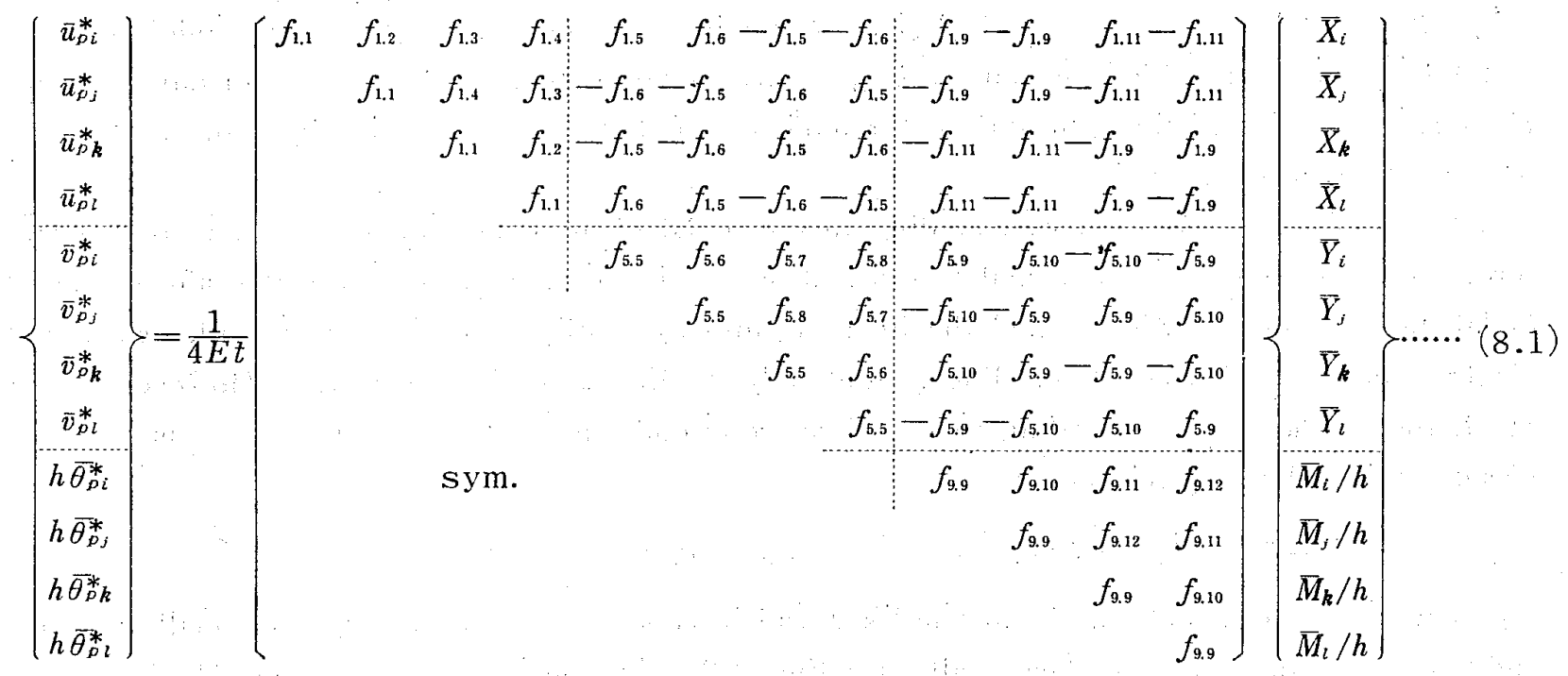

where

$f_{m . n}:$ The elements of the general flexibility matrix $\overline{\boldsymbol{F}}$ (for the four corner nodes of the boundary frame) of the shear wall (see Table 8.1)

Table 8.1 The elements $f_{m . n}$ of the general flexibility matrix $\overline{\boldsymbol{F}}$ of symmetric shear walls, expressed in terms of the elements of the fundamental flexibility matrix $F^{*}$.

\begin{tabular}{|c|c|c|c|c|c|c|c|}
\hline$f_{1.1}$ & $a_{1,1}+\left(b_{1,1}+d_{1,1}\right)$ & $f_{1.2}$ & $a_{1,1}-\left(b_{1,1}+d_{1,1}\right)$ & $f_{1.3}$ & $-a_{1,1}-\left(b_{1,1}-d_{1,1}\right)$ & $f_{1.4}$ & $-a_{1,1}+\left(b_{1,1}-d_{1,1}\right)$ \\
\hline$f_{1.5}$ & $a_{1.2}+b_{1.2}$ & $f_{1.6}$ & $-a_{1,2}+b_{1.2}$ & & & & \\
\hline$f_{1.9}$ & $b_{1.3}+d_{1.2}$ & $f_{1.11}$ & $b_{1.3}-d_{1.2}$ & & & & \\
\hline$f_{5.5}$ & $a_{2.2}+\left(b_{2.2}+c_{1.1}\right)$ & $f_{5.6}$ & $-a_{2,2}+\left(b_{2.2}-c_{1,1}\right)$ & $f_{5.7}$ & $-a_{2.2}-\left(b_{2.2}-c_{1.1}\right)$ & $f_{5.8}$ & $a_{2.2}-\left(b_{2.2}+c_{1.1}\right)$ \\
\hline$f_{5.9}$ & $b_{2.3}+c_{1,2}$ & $f_{5.10}$ & $-b_{2.3}+c_{1.2}$ & & & & \\
\hline$f_{9.9}$ & $b_{3.3}+\left(c_{2.2}+d_{2.2}\right)$ & $f_{9.10}$ & $-b_{3.3}+\left(c_{2.2}-d_{2.2}\right)$ & $f_{0.11}$ & $b_{3.3}-\left(c_{2,2}+d_{2,2}\right)$ & $f_{9.12}$ & $-b_{3.3}-\left(c_{2.2}-d_{2.2}\right)$ \\
\hline
\end{tabular}

The general flexibility matrix $\overline{\boldsymbol{F}}$ has the following properties (see the numerical example mentioned in Eq. 10.11).

1) Each sum of all the elements corresponding to the nodal external forces $\bar{X}$ or $\bar{Y}$ or $\bar{M}$ in any row of $\overline{\boldsymbol{F}}$ is zero, therefore the nodal displacements $\overline{\boldsymbol{g}}_{P} *$ due to the deformation of the shear wall subjected to the nodal external balancing components $\overline{\boldsymbol{P}} *$ are not affected by the nodal unbalancing components $\overline{\boldsymbol{P}}^{\circ}$ which equal $X^{\circ}{ }_{\mathrm{III}}$ or $Y^{\circ}{ }_{\mathrm{IV}}$ or $M^{\circ}{ }_{\mathrm{I}}$ (see Figs. 2.6, 2.8 and 2.3) and which satisfy a balancing force system together with a corresponding component of the resultant of the distributed loads. Hence, the following Eq. 8.2 is induced.

$$
\overline{\boldsymbol{F}} \overline{\boldsymbol{P}^{\circ}}=\mathbf{0}
$$

2) Each sum of all the elements corresponding to the nodal displacements $\bar{u}_{P}^{*}$ or $\bar{v}_{P} *$ or $\vec{\theta}_{P} *$ in any column of $\overline{\boldsymbol{F}}$ is zero, therefore $\sum \bar{u}_{P^{*}}, \sum \bar{v}_{P}^{*}$ and $\sum \bar{\theta}_{P} *$ of the nodal displacements due to deformation of the shear wall are identically equal to zero (see $\$ 3$ ).

3) $\overline{\boldsymbol{F}}$ is a symmetric matrix, therefore the reciprocal theorem can be applied if the nodal boundary conditions which definitely decide the nodal displacements are given.

4) When the descriptions in 1),2) and 3) are taken into consideration, three rows (columns) each respectively corresponding to $\bar{u}_{P}^{*}, \bar{v}_{P}^{*}$ and $\bar{\theta}_{P}{ }^{*}(\bar{X}, \bar{Y}$ and $\bar{M})$ are dependent rows (columns). Consequently the determinant of the matrix $\bar{F}$ is zero.

$$
\overline{\mid \boldsymbol{F}} \mid=\mathbf{0}
$$

Hence, $\overline{\boldsymbol{F}}$ is singular, and the general stiffness matrix $\overline{\boldsymbol{K}}$ mentioned in $\S 7$ cannot be derived by 
inverting the general flexibility matrix $\overline{\boldsymbol{H}^{\prime}}$. But if stable nodal support conditions which give some nodal displacements are imposed on the shear wall, the conditional stiffness matrix can be given by inverting the conditional flexibility matrix.

\section{$\$ 9$ Relations between the Stiffness Matrix and the Flexibility Matrix}

When the relations $\overline{\boldsymbol{P}}=\overline{\boldsymbol{P}} *+\overline{\boldsymbol{P}}^{\circ}$ and $\overline{\boldsymbol{F}} \overline{\boldsymbol{P}}^{\circ}=\mathbf{0}$ given by Eqs. 2.1 and 8.2 are taken into consideration, Eq. 6.21 can be rewritten as Eq. 9.1.

$$
\overline{\boldsymbol{\delta}}_{P} * \overline{\boldsymbol{F}} \overline{\boldsymbol{P}}=\overline{\boldsymbol{F}} \overline{\boldsymbol{P}} *
$$

Hence, the components $\overline{\boldsymbol{\partial}}_{P}^{*}$ are defined as the components due to the deformation of the shear ${ }_{i}^{-w a l l}$ subjected to the balancing components $\overline{\boldsymbol{P}}^{*}$ only, and the following Eq. 9.2 is obtained.

$$
\overline{\boldsymbol{P}}^{*}=\overline{\boldsymbol{K}} \overline{\boldsymbol{\delta}}_{P^{*}}^{*}
$$

When the relation $\overline{\boldsymbol{\delta}}_{P} *=\overline{\boldsymbol{F}} \overline{\boldsymbol{P}}$ given by Eq. 6.21 is substituted into Eq. 9.2 the following Eq. 9.3 is derived.

$$
\overline{\boldsymbol{P}}^{*}=\overline{\boldsymbol{K}} \overline{\boldsymbol{F}} \overline{\boldsymbol{P}}
$$

If Eq. 9.3 is equated to the relation $\overline{\boldsymbol{P}^{*}}={ }_{1} \boldsymbol{T}_{P_{12} \boldsymbol{T}_{P_{1}}} \overline{\boldsymbol{P}}$ given by Eq. 2.12, the product of the"general stiffness matrix $\overline{\boldsymbol{K}}$ and general fexibility matrix $\overline{\boldsymbol{F}}$ can be given by Eq. 9.4.

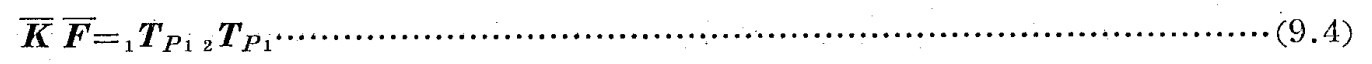

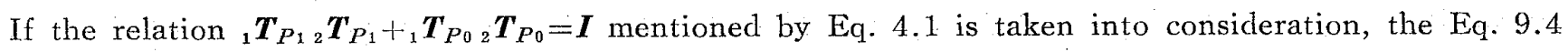
can be rewritten as Eq. 9.5.

$$
\overline{\boldsymbol{K}} \overline{\boldsymbol{F}}=\boldsymbol{I}-{ }_{1} \boldsymbol{T}_{P_{0}{ }_{2}} \boldsymbol{T}_{P 0}
$$

When the relations $\overline{\boldsymbol{\delta}}=\overline{\boldsymbol{\delta}}^{*}+\overline{\boldsymbol{\delta}}^{\circ}$ and $\overline{\boldsymbol{K}} \overline{\boldsymbol{\partial}}^{\circ}=\mathbf{0}$ given by Eqs. 3.1 and 7.2 are taken into consideration, Eq. 6.9 can be rewritten as Eq. 9.6.

$$
\overline{\boldsymbol{P}}_{\delta}^{*}=\overline{\boldsymbol{K}} \overline{\boldsymbol{\delta}}=\overline{\boldsymbol{K}} \overline{\boldsymbol{\delta}^{*}}
$$

Hence, the components $\overline{\boldsymbol{P}}_{\delta}{ }^{*}$ are defined as the components which cause the components $\overline{\boldsymbol{\partial}^{*}}$ due to the deformation of the shear wall, and the following Eq. 9.7 is obtained.

$$
\overline{\boldsymbol{\delta}} * \overline{\boldsymbol{F}} \overline{\boldsymbol{P}}_{\delta}^{*}
$$

When the relation $\overline{\boldsymbol{P}}_{\hat{\delta}}^{*}=\overline{\boldsymbol{K}} \overline{\boldsymbol{\delta}}$ given by Eq. 6.9 is substituted into Eq. 9.7, the following Eq. 9.8 is derived.

$$
\overline{\boldsymbol{\delta}}^{*}=\overline{\boldsymbol{F}} \overline{\boldsymbol{K}} \overline{\boldsymbol{\delta}}
$$

If Eq. 9.8 is equated to the relation $\overline{\boldsymbol{\delta}}^{*}={ }_{1} \boldsymbol{T}_{\tilde{\delta} 12} \boldsymbol{T}_{\tilde{\delta} 1} \overline{\boldsymbol{\delta}}$ given by Eq. 3.12 , the product of the general flexibility matrix $\overline{\boldsymbol{F}}$ and general stiffness matrix $\overline{\boldsymbol{K}}$ can be given by Eq. 9.9.

$$
\overline{\boldsymbol{F}} \overline{\boldsymbol{K}}={ }_{1} \boldsymbol{T}_{\delta 1} \boldsymbol{T}_{\delta 1}
$$

If the relation ${ }_{1} \boldsymbol{T}_{\tilde{\delta} 12} \boldsymbol{T}_{i \mathfrak{1}}+{ }_{1} \boldsymbol{T}_{\tilde{0} 02} \boldsymbol{T}_{\hat{0} 0}=\boldsymbol{I}$ mentioned by Eq. 4.9 is taken into consideration, the Eq. 9.9 can be rewritten as Eq. 9.10.

$$
\overline{\boldsymbol{F}} \overline{\boldsymbol{K}}=\boldsymbol{I}-{ }_{1} \boldsymbol{T}_{\grave{\delta} 02} \boldsymbol{T}_{\hat{\delta} 0}
$$

The products ${ }_{1} \boldsymbol{T}_{P_{1}{ }_{2}} \boldsymbol{T}_{P_{1}}$ in Eq. 9.4, ${ }_{1} \boldsymbol{T}_{P_{0} 2} \boldsymbol{T}_{P_{0}}$ in Eq. 9.5, ${ }_{1} \boldsymbol{T}_{\delta_{11}} \boldsymbol{T}_{\hat{0} 1}$ in Eq. 9.9 and ${ }_{1} \boldsymbol{T}_{\partial 02} \boldsymbol{T}_{\delta 0}$ in Eq. 9.10 are not identity matrix (see Eqs. 2.14, 2.15, 3.14 and 3.15), therefore the products $\overline{\boldsymbol{K}} \overline{\boldsymbol{F}}$ and $\overline{\boldsymbol{F}} \overline{\boldsymbol{K}}$ given by Eqs. 9.4,9.5,9.9 and 9.10 are neither identity matrix nor null matrix, and $\overline{\boldsymbol{K}}$ and $\overline{\boldsymbol{F}}$ cannot be given as inverse matrix of $\overline{\boldsymbol{F}}$ and $\overline{\boldsymbol{K}}$ whose determinants are zero (see Eqs. 7.3 and 8.3).

If it is taken into consideration that $\overline{\boldsymbol{K}}$ and $\overline{\boldsymbol{F}}$ are symmetric matrix, the Eq. 9.11 is derived.

$$
\overline{\boldsymbol{K}} \overline{\boldsymbol{F}}=\overline{\boldsymbol{K}}^{t} \overline{\boldsymbol{F}}^{t}=[\overline{\boldsymbol{F}} \overline{\boldsymbol{K}}]^{t}
$$

When each side of Eq. 6.20 is premultiplied by the transformation matrix ${ }_{2} \boldsymbol{T}_{\delta 1}$ to transform $\overline{\boldsymbol{\delta}}$ into $\boldsymbol{\partial}^{\text {** }}$ (see Eqs. 3.8, 3.7 and 3.6) and is postmultiplied by the transformation matrix ${ }_{1} \boldsymbol{T}_{P_{1}}$ to transform $\boldsymbol{P}^{*}$ into $\overline{\boldsymbol{P}}^{*}$ (see Eqs. 2.2, 2.4 and 2.5), the following Eq. 9.12 is derived.

$$
{ }_{2} \boldsymbol{T}_{\grave{\partial} 1} \bar{F}_{1} T_{P_{1}}={ }_{2} T_{\delta 11} T_{\grave{o} 1} F^{*}{ }_{2} T_{P_{11}} T_{P_{1}}
$$

When the relations ${ }_{2} \boldsymbol{T}_{P_{11}} \boldsymbol{T}_{P_{1}}=\boldsymbol{I}$ and ${ }_{2} \boldsymbol{T}_{\hat{\nu} 11} \boldsymbol{T}_{\hat{\imath} 1}=\boldsymbol{I}$ given by Eqs. 4.5 and 4.13 are taken into consideration, the Eq. 9.12 can be rewritten as Eq. 9.13.

$$
\boldsymbol{F}^{*}={ }_{2} \boldsymbol{T}_{\tilde{\delta} 1} \overline{\boldsymbol{F}}_{1} \boldsymbol{T}_{P_{1}}
$$

When each side of Eq. 6.7 is premultiplied by the transformation matrix ${ }_{2} \boldsymbol{T}_{P_{1}}$ to transform $\overline{\boldsymbol{P}}$ 
into $\boldsymbol{P}^{*}$ (see Eqs. 2.8, 2.6 and 2.7) and is postmultiplied by the transformation matrix, $\boldsymbol{T}_{\delta 1}$ to transform $\boldsymbol{\delta}^{*}$ into $\overline{\boldsymbol{d}}^{*}$ (see Eq. $3.2,3.4$ and 3.5), the following Eq. 9.14 is derived.

$$
{ }_{2} T_{P_{1}} \bar{K}_{1} T_{\delta 1}={ }_{2} T_{P_{1} 1} T_{P_{1}} K^{*}{ }_{2} T_{\delta 11} T_{\delta 1}
$$

When the relations ${ }_{2} \boldsymbol{T}_{P_{11}} \boldsymbol{T}_{P_{1}}=\boldsymbol{I}$ and ${ }_{2} \boldsymbol{T}_{\delta 11} \boldsymbol{T}_{\delta 1}=\boldsymbol{I}$ given by Eqs. 4.5 and 4.13 are taken into consideration, the Eq. 9.14 can be rewritten as Eq. 9.15.

$$
K *={ }_{2} T_{P 1} \bar{K}_{1} T_{\delta 1}
$$

When $\boldsymbol{F}^{*}$ given by Eq. 9.13 is substituted into the relation $\overline{\boldsymbol{K}}={ }_{1} \boldsymbol{T}_{P_{1}} \overline{\boldsymbol{F}}^{*-1}{ }_{2} \boldsymbol{T}_{\tilde{\delta} \mathrm{i}}$ given by Eq. 6.7, the general stiffness matrix $\overline{\boldsymbol{K}}$ expressed in the general flexibility matrix $\overline{\boldsymbol{F}}$ is given by Eq. 9.16.

$$
\bar{K}={ }_{1} T_{P_{1}}\left[{ }_{2} T_{\delta 1} \bar{F}_{1} T_{P_{1}}\right]^{-1}{ }_{2} T_{\delta 1}
$$

When the relation ${ }_{1} \boldsymbol{T}_{P_{1}}=4{ }_{2} \boldsymbol{T}_{\hat{\delta} 1}$ given by Eq. 4.18 is taken into consideration, the Eq. 9.16 is rewritten as Eqs. 9.17 and 9.18.

$$
\begin{aligned}
\bar{K} & \left.={ }_{2} T_{\delta 1}{ }^{t} \cdot{ }_{2} T_{\delta 1} \bar{F}_{2} T_{\delta 1}{ }^{t}\right]^{-1}{ }_{2} T_{\delta 1} \cdots \\
& ={ }_{1} T_{P_{1}}\left[{ }_{1} T_{P_{1}}{ }^{t} \bar{F}_{1} T_{P_{1}}\right]^{-1}{ }_{1} T_{P_{1}}{ }^{t}
\end{aligned}
$$

When $\boldsymbol{K}^{*}$ given by Eq. 9.15 is substituted into the relation $\overline{\boldsymbol{F}}={ }_{1} \boldsymbol{T}_{\tilde{o} 1} \boldsymbol{K}^{*-1}{ }_{2} \boldsymbol{T}_{P_{1}}$ given by Eq. 6.20, the general flexibility matrix $\bar{F}$ expressed in the general stiffness matrix $\bar{K}$ is given by Eq. 9.19.

$$
\bar{F}={ }_{1} T_{\delta 1}\left[{ }_{2} T_{P_{1}} \bar{K}_{1} T_{\delta 1}\right]^{-1}{ }_{2} T_{P_{1}}
$$

When the relation ${ }_{1} \boldsymbol{T}_{\hat{o} 1}=4_{2} \boldsymbol{T}_{P_{1}}$ given by Eq. 4.21 is taken into consideration, the Eq. 9.19 is rewritten as Eqs. 9.20 and 9.21 .

$$
\begin{aligned}
\overline{\boldsymbol{F}} & ={ }_{2} \boldsymbol{T}_{P_{1}}{ }^{t}\left[{ }_{2} \boldsymbol{T}_{P_{1}} \overline{\boldsymbol{K}}_{2} \boldsymbol{T}_{P_{1}}{ }^{t}\right]^{-1}{ }_{2} \boldsymbol{T}_{P_{1}} \\
& ={ }_{1} \boldsymbol{T}_{\delta 1}\left[{ }_{1} \boldsymbol{T}_{\delta 1}{ }^{t} \bar{K}_{1} \boldsymbol{T}_{\delta 1}\right]^{-1}{ }_{1} T_{\delta 1}{ }^{t} \ldots
\end{aligned}
$$

The flow chart of the derivation process of the general stiffness matrix $\overline{\boldsymbol{K}}$ and general flexibility matrix $\bar{F}$, and the numbers of the related equations are mentioned in Fig. 9.1.

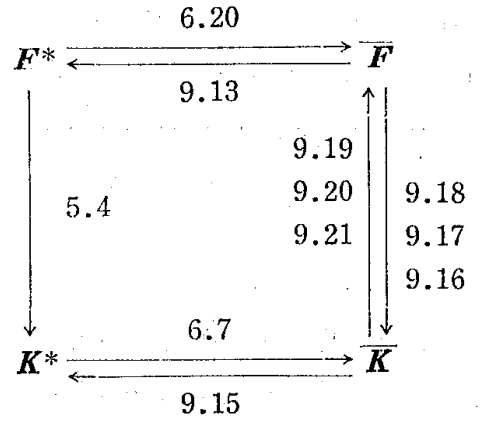

Fig. 9.1 The flow chart showing the computation process of $\overline{\boldsymbol{K}}, \overline{\boldsymbol{F}}$ and the numbers of the related equations.

\section{CONCLUSIONS}

When the shapes of shear walls are symmetric with regard to their longitudinal and transversal center lines and the shear walls are isotropic elastic bodies, the elements of the general stiffness matrix $\overline{\boldsymbol{K}}$ and general flexibility matrix $\overline{\boldsymbol{F}}$ are expressed in terms of the elements of $\boldsymbol{F}^{*}$ (see Tables 7.1 and 8.1). Thus, the physical meaning of the elements of $\overline{\boldsymbol{K}}$ and $\overline{\boldsymbol{F}}$ are revealed.

The determinants of $\overline{\boldsymbol{K}}$ and $\overline{\boldsymbol{F}}$ are zero, because the framed shear wall whose nodal displacements are not given as the stable nodal support conditions can move freely by its rigid-body motion, and its nodal displacements are indeterminate. Therefore neither of $\overline{\boldsymbol{K}}$ and $\overline{\boldsymbol{F}}$ can be given by inverting the other.

$\overline{\boldsymbol{K}}$ can be expressed in terms of $\overline{\boldsymbol{F}}$ by using the transformation matrix ${ }_{2} \boldsymbol{T}_{\tilde{\nu} 1}$ to transform $\overline{\boldsymbol{\delta}}$ into $\boldsymbol{\delta}^{*}$ or the transformation matrix ${ }_{1} \boldsymbol{T}_{P_{1}}$ to transform $\boldsymbol{P}^{*}$ into $\overline{\boldsymbol{P}^{*}}$ (see Eqs. 9.17 and 9.18), where ${ }_{1} \boldsymbol{T}_{P_{1}}=4_{2} \boldsymbol{T}_{\boldsymbol{\delta} \mathbf{1}}{ }^{t}$ (see Eq. 4.18).

$\bar{F}$ can be expressed in terms of $\overline{\boldsymbol{K}}$ by using the transformation matrix ${ }_{2} \boldsymbol{T}_{P_{1}}$ to transform $\overline{\boldsymbol{P}}$ into $\boldsymbol{P} *$ or the transformation matrix ${ }_{1} \boldsymbol{T}_{\bar{\delta} 1}$ to transform $\boldsymbol{\delta}^{*}$ into $\overline{\boldsymbol{\delta}^{*}}$ (see Eqs. 9.20 and 9.21), where ${ }_{1} \boldsymbol{T}_{\delta 1}=4_{2} \boldsymbol{T}_{P_{1}}{ }^{t}$ (see Eq. $4: 21$ ). 


\section{耐震壁の節点外力と節点变位の関係（第 4 報）}

\section{Stiffness Matrix 脑よび Flexibility Matrix-}

正会員 富 井 政 英*
正会員山 $川$ 哲 雄**

序

紙面の都合で本論文は 5 編に分割して連載する。

\section{$\$ 7$ 耐震壁の節点に関する一般的な Stiffness Matrix の特性}

$\$ 6$ で述べたよらに一般的な Stiffness Matrix $\bar{K}$ は，要素が解析 ${ }^{1) ~ 5) ~}$ Flexibility Matrix $\boldsymbol{F}^{*}$ の逆マトリックスで表わされる (6.7 式参照)。

$\overline{\boldsymbol{K}}$ の要素 $k_{m . n}$ は， $\overline{\boldsymbol{P}_{\delta}^{*}}=\overline{\boldsymbol{K}} \overline{\boldsymbol{\delta}}$ (6.9 式参照) を詳細に 示した 7.1 式に示すように定義する。耐震壁の形状が 縦横軸関して対称で，かつその材質が等方性である場 合は， $k_{m . n}$ が基本 Stiffness Matrix $\boldsymbol{K}^{*}$ の要素 (5.5 式参照) で 7.1 表のよらに表わされる。なお， $\boldsymbol{K} *$ の 要素は，解析 ${ }^{125)}$ または実験によって与えられる $\boldsymbol{F}^{*}$ * 要素で表わされる $(5.2,5.5,5.6$ 式参照)。

$\overline{\boldsymbol{K}}$ には次の特性がある (10.9 式に示した数值計算例 参照)。

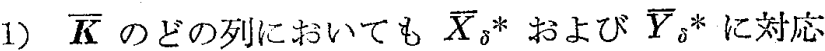
する要素の和はそれぞれ零である。ゆえに， $\bar{x}$ 叔よ び $\bar{y}$ 方向に関する力の釣合は恒等的に満足されて いる。しかしながら， $\bar{K}$ のどの列においても $\bar{M}_{\delta}^{*}$ に対応する要素の和は零にならない。これは，モー メントの釣合は $\bar{X}_{o}^{*}, \bar{Y}_{\delta}^{*}$ を考慮に入れなければ ならないからで亦るそこで， $\bar{M}_{\delta}^{*}$ に対応した列 要素の和に， $\bar{X}_{i j} *$ と $\bar{X}_{\dot{j} j} *$ に対応した要素 $k_{m, n}$ の $1 / 2, \bar{X}_{\partial k^{*}}$ と $\bar{X}_{\delta l} *$ に刘応した $k_{m . n}$ の $-1 / 2$, $\bar{Y}_{i j} *$ と $\bar{Y}_{\delta} t^{*}$ に対灾した $k_{m . u}$ の $-\lambda / 2, \bar{Y}_{\delta j} *$ と $\bar{Y}_{i k} *$ に対応した $k_{m . n}$ の $\lambda / 2$ t加えて，はじめて

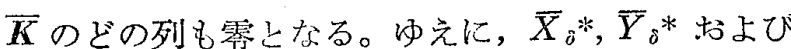
$\bar{M}_{\hat{o}}{ }^{*}$ に関するモーメントの鈞合は恒等的に満足さ れている。

2)、 $\overline{\boldsymbol{K}}$ のどの行に抒いても $\bar{u} や \bar{v}$ に対応する要素

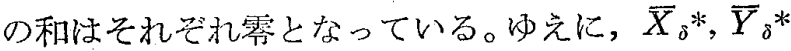
括よび $\bar{M}_{\delta}^{*}$ 江耐震壁の剛体運動 $u^{\circ}$ 打よび $0^{\circ}$ に よって生ずる尔机ぞれ等しい各節点変位 $\ddot{u}$ および テによっては影響されない。しかしながら $\overline{\boldsymbol{K}}$ のど

* 九州大学工学部教授・工博

*** 清水建設 (株) 䃐究所・工修 昭和 49 年 12 月 17 日本稿受理・討諭期限昭和 51 年 5 月末日
の行に沶いてものに対応する要素の和法零になら ない。これは耐震壁の風体回転運動 $\theta^{\circ}$ によって $\theta^{\circ}$ に等しい節点回転角 $\bar{\theta}$ のほかに節点変位 $\vec{u}, \bar{v}$ が

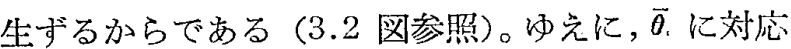
した行要溸の和に， $\vec{u}_{i}$ と $u_{j}$ に対空した要素 $k_{m . n}$ の $1 / 2 ， \bar{u}_{k}$ と $u_{l}$ に対応した $k_{m, n}$.の $-1 / 2, \bar{v}_{i}$ と $\vec{v}_{l}$ に対応した $k_{m . n}$ の- $-2 / 2$ 倍, $\bar{v}_{j}$ と $\bar{v}_{k}$ に刘応 した $k_{m . n}$ の $\lambda / 2$ 偣を加光ると，は心゙めて $\overline{\boldsymbol{K}}$ のど の行も零となる。ここに $\theta^{\circ}$ は微小でなければなら ない。こ机怯本諭の解析が線型微小变位理論によ。

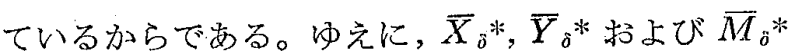
は微小剛体回転連動 $\theta^{\circ}$ によっても影響されない。 したがって，7.2 式を得る。

3） $\overline{\boldsymbol{K}}$ 注対称マトリックスであるので，末知節点変 位が一義的に求まるような節点支持条件が与えられ ると，相反定理が成立する。

4）以上記述した 1)，2，，3）項を考慮すると， $\bar{X}_{\delta}{ }^{*}$, $\bar{Y}_{\delta}^{*}$ および $\bar{M}_{\delta}^{*}(\bar{u}, \bar{v}$ および $\vec{\theta})$ にそ机ぞれ䇃応 する 3 行 (列) や, $\bar{X}_{0}^{*}(\bar{u})$ に効応する1行 (列) と力の作用線が一致しない $\bar{Y}_{\delta}^{*}(\overline{\mathcal{V}})$ に対応する 2 行(列)，あるいはまた作用線が一致しない $\bar{X}_{\delta} *(\bar{u})$ に対応した 2 行 (列) と $\bar{Y}_{\delta}^{*}(\bar{v})$ に対店した 1 行 (列) は徒属行 (列) である。河えに, $\overline{\boldsymbol{K}}$ の行列式 の值が零となり， 7.3 式が得られる。また $\overline{\boldsymbol{K}}$ は特 異となり，\$8 で述べる耐震壁の一般的な Flexibility Matrix $\overline{\boldsymbol{F}}$ は $\overline{\boldsymbol{K}}$ の逆マトリックスとしては 与えられない。しかし安定な節点支持条件が与えら れると, Flexibility Matrix は Stiffness Matrix の逆マトリックスとして与えられる。

\section{\$8 耐震壁の節点に関する一般的な Flexibility Matrix の特性}

\$6 で述べたように，一般的な Flexibility Matrix $\boldsymbol{F}$

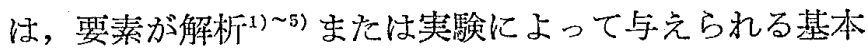
Flexibility Matrix $\boldsymbol{F}^{*}$ で表わされる(6.20 式参照)。

$\overline{\boldsymbol{T}}$ の要素 $f_{m . n}$ は， $\overline{\boldsymbol{D}}_{P^{*}}=\overline{\boldsymbol{F}} \overline{\boldsymbol{P}}$ (6.21 式参照) 詳細 に示した 8.1 式に示すように定義する。耐震壁の形状 が縦横軸に対称で，かつその材質が等方性である場合は $f_{m \cdot n}$ が基本 Flexibility Matrix $\boldsymbol{F}^{*}$ の要素 (5.2 式参 照) で 8.1 表のように表わされる。なお， $\boldsymbol{F}^{*}$ の要素 


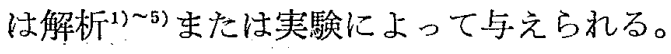

$\overline{\boldsymbol{F}}$ には次の特性がある（10.11 式に示した数值計算 例参照)。

1) $\bar{F}$ のどの行においても， $\bar{X}, \bar{Y}$ および $\bar{M}$ に対 応する要素の和はそれぞれ零である。ゆえに，力の 釣合を満足する節点外力成分 $\overline{\boldsymbol{P}} *$ の夕作用する而讨 震壁の変形に関係する節点变位 $\overrightarrow{\boldsymbol{\delta}}_{P} *$ は, 各節点外 力が $X^{\circ}$ III $Y^{\circ}{ }^{\circ}, M^{\circ}{ }_{1}(2.6,2.8,2.3$ 図参照) に 等しく，かつ中間荷重の合力と釣合力系を構成する 節点外力の不釣合成分 $\boldsymbol{\boldsymbol { P }}^{\circ}$ によっては影響されな い。したがって 8.2 式が得られる。

2） $\bar{F}$ のどの列においても， $\bar{u}_{P^{*}}, \bar{v}_{P}{ }^{*}, \bar{\theta}_{P} *$ に対忍す

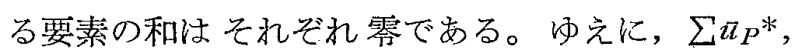
$\sum \bar{v}_{P}{ }^{*}$ および $\sum \widehat{\theta}_{P}$ * はそれぞれ恒等的に零に等し い( 3 参照)。

3) $\overline{\boldsymbol{F}}$ は対称マトリックスであるので,末知節点変位 が一義的に求まるような節点支持条件が与充られる と, 相反定理が成立与る。

4) 以上述べた 1)，2，3）項を考慮すると, $\bar{u}_{P}^{*}$, $\bar{v}_{P}{ }^{*}$ および $\bar{\theta}_{P}^{*}(\bar{X}, \bar{Y}$ および $\bar{M})$ にそれぞれ対 応する 3 行 (列) は従属行 (列) である。ゆえに， $\bar{F}$ の行列式の值は零となり，8.3 式が得られる。ま た $\overline{\boldsymbol{F}}$ は特異となり，\$7で述べた $\overline{\boldsymbol{K}}$ は $\overline{\boldsymbol{F}}$ の逆マ トリックスとしては与えられない。しかし安定な 節点支持条件が与えられると Stiffness Matrix は Flexibility Matrix の逆マトリックスとして与え られる。

\section{$\$ 9$ Stiffness Matrix $\llcorner$ Flexibility Matrix $の$} 関係

2.1 朽よび 8.2 式を考慮すると，6.21 式が 9.1 式の ように書き直される。ゆえに， $\overline{\boldsymbol{D}}_{P}^{*}$ は $\overline{\boldsymbol{P}} *$ のみが作用 する耐震壁の弾性変形による節点変位成分として定義さ れ，9.2 式が得られる。6.21 式を9.2 式に代入する と, 9.3 式が得られる。9.3 式を 2.12 式に等值すると $\overline{\boldsymbol{K}}$ と $\overline{\boldsymbol{F}}$ の積が 9.4 式で与えられる。

4.1 式を考慮すると，9.4 式が 9.5 式のように書き直 され，3.1 および 7.2 式を考慮すると， 6.9 式が 9.6

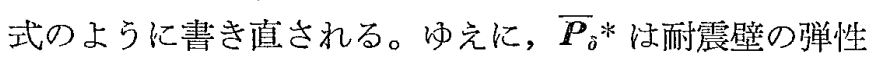
変形による節点変位成分 $\overline{\boldsymbol{\delta}}^{*}$ を生しささせ節点外力成分 として定義され，9.7 式が得られる。6.9 式を9.7 式に 代入すると， 9.8 式が誘導される。

9.8 式を 3.12 式と等值すると， $\overline{\boldsymbol{F}}$ と $\overline{\boldsymbol{K}}$ の積が 9.9 式で与光られる。4.9 式を考慮すると，9.9 式が 9.10 式のよらに書き直される。

9.4 式の ${ }_{1} \boldsymbol{T}_{\boldsymbol{P}_{12}} \boldsymbol{T}_{\boldsymbol{P}_{1}}, 9.5$ 式の ${ }_{\mathrm{i}} \boldsymbol{T}_{\boldsymbol{P}_{2}{ }_{2}} \boldsymbol{T}_{\boldsymbol{P}_{0}}, 9.9$ 式の ${ }_{1} T_{\delta 12} T_{\delta 1}$ および 9.10 式の ${ }_{1} T_{002} T_{\hat{0} 0}$ が単位マトリック スでないことを考慮すると $(2.14,2.15,3.14,3.15$ 式 参照)，9.4，9.5，9.9 抢よび 9.10 式で与えたマトリ
ックス積 $\overline{\boldsymbol{K}} \overline{\boldsymbol{F}}$ と $\overline{\boldsymbol{F}} \overline{\boldsymbol{K}}$ は，単位マトリックスでも零マ トリックスでもない。ゆえに, $\overline{\boldsymbol{K}}$ と $\overline{\boldsymbol{F}}$ 注, 行列式の值 が零である $\overline{\boldsymbol{F}}$ と $\overline{\boldsymbol{K}}$ の逆マトリックスとして与えられ ない (7.3,8.3 式参照)。

$\overline{\boldsymbol{K}}$ と $\overline{\boldsymbol{F}}$ が対称マトリックスであることを考慮する と, 9.11 式が誘導される。

$\overline{\boldsymbol{\delta}}$ を $\boldsymbol{\delta}^{*}$ に変撸する変換マトリックス ${ }_{2} \boldsymbol{T}_{\delta 1}(3.8,3.7$, 3.6 式参照） 6.20 式の雨辺の左から乗し，次に $\boldsymbol{P} *$ を $\overline{\boldsymbol{P}}^{*}$ に変換する変換マトリックス ${ }_{1} \boldsymbol{T}_{\boldsymbol{P}_{\mathbf{1}}}(2.2,2.4$, 2.5 式参照）を 6.20 式の両辺の右から乘ずると, 9.12 式が得られる。4.5 および 4.13 式考考慮すると, 9.12 式汃 9.13 式のように書き直される。

$\overline{\boldsymbol{P}} \boldsymbol{P} *$ に変換する変换マトリックス ${ }_{2} \boldsymbol{T}_{\boldsymbol{P}_{1}}(2.8$, $2.6 ， 2.7$ 式参照) 䘮 6.7 式の両辺の左から乗し，次に $\boldsymbol{\delta}^{*}$ を $\overline{\boldsymbol{\delta}}^{*}$ に変換する変換マトリックス ${ }_{1} \boldsymbol{T}_{\delta 1}(3.2,3.4$, 3.5 式参照）を 6.7 式の雨辺の右から乘ずると，9.14 式が得られる。4.5 および 4.13 式を考慮すると， 9.14 式が 9.15 式のように書き值される。

9.13 式莸 6.7 式に代入すると, 一般的 Flexibility Matrix $\bar{F}$ から一般的 Stiffness Matrix $\bar{K}$ を求める 9.16 式が誘導される。 4.18 式支考慮すると, 9.16 式 は 9.17 および 9.18 式のよらに書き直される。

9.15 式を 6.20 式に代入すると，一般的 Stiffness Matrix $\overline{\boldsymbol{K}}$ 加ら一般的 Flexibility Matrix $\overline{\boldsymbol{F}}$ 求める 9.19 式が誘導される。4.21 式を考慮すると, 9.19 式 は 9.20 および 9.21 式のように書き直される。

$\overline{\boldsymbol{K}}$ と $\overline{\boldsymbol{F}}$ の誘導過程の流れ図とその関係式番号を 9.1 困に示守。

\section{結 論}

而震壁の形状が縦横軸に関して対称で，かつその材質 が等方性である場合， $\overline{\boldsymbol{K}}$ および $\overline{\boldsymbol{F}}$ の要素は $\boldsymbol{F}^{*}$ の要 素で表わされる(7.1,8.1 式参照)。

$\overline{\boldsymbol{K}}$ と $\overline{\boldsymbol{F}}$ の要素の物理的意味も明らかにした。

$\overline{\boldsymbol{K}}$ と $\overline{\boldsymbol{F}}$ の行列式の值㥏である。なぜなら，耐震壁 の節点変位吕安定な節点支持条件として与えられない限 り, 自由な岡体運動が可能で, 節点外力に対して節点変 位が一義的に定まらないからである。したがって， と严は枑いに互の逆マトリックスとして与えられな Vo

${ }_{1} \boldsymbol{T}_{P_{1}}=4{ }_{2} \boldsymbol{T}_{\delta 1}{ }^{\boldsymbol{t}}$ (4.18 式参照) 它考慮すると, $\overline{\boldsymbol{d}}$ 它 $\boldsymbol{\delta}^{*}$ に変掺する変換マトリックス ${ }_{2} \boldsymbol{T}_{\delta 1}$ ，または $\boldsymbol{P} *$ を $\overline{\boldsymbol{P}}^{*}$ に変挨する変換マトリックス ${ }_{1} T_{P_{1}}$ 学使って, $\bar{F}$ から $\bar{K}$ を求めることができる (9.17，9.18 式参照)。

${ }_{1} \boldsymbol{T}_{\delta 1}=4{ }_{2} \boldsymbol{T}_{P_{1}}{ }^{t}$ (4.21 式参照) 党考慮すると, $\overline{\boldsymbol{P}} \boldsymbol{P} *$ に変撸する変換マトリックス ${ }_{2} T_{P_{1}}$, または $\bar{\delta}^{*} を \delta^{*} に$ 変換する変換マトリックス ${ }_{1} \boldsymbol{T}_{\partial 1}$ 定使って, $\overline{\boldsymbol{K}}$ から $\overline{\boldsymbol{F}}$ を求めることができる (9.20,9.21 式参照)。 